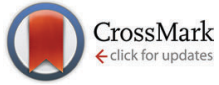

Cite this: J. Mater. Chem. B, 2015, 3, 6501

Received 15th December 2014 Accepted 6th July 2015

DOI: $10.1039 / c 4 t b 02065 k$

www.rsc.org/MaterialsB

\section{Cationic poly(amidoamine) promotes cytosolic delivery of bovine RNase A in melanoma cells, while maintaining its cellular toxicity $\dagger$}

\begin{abstract}
Julie L. N. Dubois $\ddagger$ and Nathalie Lavignac*
Ribonucleases are known to cleave ribonucleic acids, inducing cell death. RNase A, a member of the ribonuclease family, generally displayed poor in vitro activity. This has been attributed to factors such as low intracellular delivery. Poly(amidoamine)s have been used to promote the translocation of nonpermeant proteins to the cytosol. Our objective was to demonstrate that poly(amidoamine)s could potentially promote the delivery of RNase A to selected cell line. Interactions of three cationic poly(amidoamine)s (P1, P2 and ISA1) with wild-type bovine RNase A were investigated using gel retardation assays, DLS and microcalorimetry. Although the polymers and the protein are essentially cationic at physiological $\mathrm{pH}$, complexation between the PAAs and RNase A was observed. The high sensitivity differential scanning calorimetry (HSDSC) thermograms demonstrated that the thermal stability of the protein was reduced when complexed with ISA1 $\left(T_{\max }\right.$ decreased by $6.5^{\circ} \mathrm{C}$ ) but was not affected by $\mathrm{P} 1$ and P2. All the polymers displayed low cytotoxicity towards non-cancerous cells $\left(\mathrm{IC}_{50}>\right.$ $3.5 \mathrm{mg} \mathrm{mL}^{-1}$ ). While RNase A alone was not toxic to mouse melanoma cells (B16F1), P1 was able to promote cytosolic delivery of biologically active RNase $A$, increasing cell death $\left(I C_{50}=0.09 \mathrm{mg} \mathrm{mL}^{-1}\right)$.
\end{abstract}

\section{Introduction}

Studies in the early 1950s reported the anticancer activity of high doses of bovine ribonuclease A (RNase A). ${ }^{1}$ However, over the years, the cytotoxicity of RNase A has been controversial and efforts have been made to develop more potent ribonucleases such as Onconase. Still, Onconase is of non-mammalian origin and is known to display some nephro- and neurotoxicity. ${ }^{2}$ The low efficiency of RNase A has been attributed to poor intracellular delivery, inhibition by the ribonuclease inhibitor (RI) and short half-life. ${ }^{2}$ Bovine seminal RNase (BS-RNase) is a naturally occurring dimeric ribonuclease. ${ }^{3}$ It is composed of two subunits (M), which are either linked by simple disulphide bonds $(\mathrm{M}=\mathrm{M}$ form $)$ or via additional non-covalent interactions, resulting from the swapping of the $\mathrm{N}$-terminal $\alpha$-helices $(\mathrm{M} \times \mathrm{M}$ form). These dimeric structures favour evasion from the RI and confers enhanced cytotoxicity to the $\mathbf{M} \times \mathbf{M}$ form, more stable under the reducing environment of the cytosol. ${ }^{3}$

Medway School of Pharmacy, Universities of Kent and Greenwich at Medway, Central Avenue, Chatham ME4 4TB, UK. E-mail:n.lavignac@kent.ac.uk $\dagger$ Electronic supplementary information (ESI) available: MP4 file for the 3D animation representing the surface of bovine RNase A (PDB: 1kf5) including the electrostatic potential and hydrophobic patches. See DOI: 10.1039/c4tb02065k \# Current address: Laboratoire ERRMECe, Université de Cergy-Pontoise, 2 av. Adolphe Chauvin BP222, 95302 Cergy-Pontoise Cedex, France.
Although dimerisation may not always grant the highest cytotoxicity, ${ }^{4}$ strategies to obtain RI resistant RNase A, have led to the synthesis of dimeric RNase A endowed with different degree of cytotoxicity ${ }^{3,5-8}$. Microinjection of ribonuclease A into the cytosol of Xenopus oocytes and NIH/3T3 cells confirmed its cytotoxicity and demonstrated that the protein was potent at low doses. ${ }^{9,10}$ More recent studies have revealed that enhanced cytosolic delivery can compensate the inhibitory action of the RI. ${ }^{11,12}$ To that effect, different methods such as cationisation ${ }^{13-17}$ or conjugation to non-biodegradable synthetic polymers ${ }^{18-20}$ have been developed. Encouraging results were obtained but the catalytic activity of the ribonuclease bioconjugates was often decreased. ${ }^{15,16}$

Poly(amidoamine)s (PAAs) are biodegradable polymers and are generally less cytotoxic compared to most polycations used as nanocarriers. ${ }^{21}$ They are synthesised by Michael addition polymerisation and possess secondary or tertiary amines in the polymer backbone. Poly(amidoamine)s are $\mathrm{pH}$-responsive polyelectrolytes and upon acidification of their environment their conformation will change from a coiled structure to a more extended structure with increased radius of gyration. This $\mathrm{pH}$ responsiveness has also been observed in a biological environment and increased haemoglobin release has been noticed at acidic $\mathrm{pH}$ when red blood cells were incubated with some poly(amidoamine)s. ${ }^{21}$ The capacity of the PAAs to be protonated at acidic $\mathrm{pH}$ allows them to potentially destabilise the endosomal 
or lysosomal membranes and act as endosomolytic (or lysosomolytic) polymers. ${ }^{22}$ Hence, some poly(amidoamine)s have been used to promote the cytosolic delivery of drugs ${ }^{21,23}$ and biomacromolecules $^{24-26}$ including non-permeant toxins ${ }^{27-29}$ i.e. protein toxins which are not able to translocate to the cytosol of the cells.

We recently synthesised some cationic poly(amidoamine)s able to interact with and stabilise BSA. ${ }^{30}$ We hypothesised that these PAAs could be used to promote the translocation of wildtype RNase A into the cytosol of the cells. Using gel retardation assays and high sensitivity differential scanning calorimetry (HSDSC), we evaluated the interaction of the polymers with the protein. The complexes obtained upon incubation were characterised by DLS. The cellular uptake of the protein in presence or absence of the PAAs was evaluated at $37{ }^{\circ} \mathrm{C}$ and $4{ }^{\circ} \mathrm{C}$ using flow cytometry. RNase A induces cell death by cleaving RNA located in the cytosol. The retention of its biological activity and the cytosolic delivery of the protein was determined indirectly by measuring the cells viability following incubation with the PAA/RNase A complexes, using a non-toxic concentration of RNase A.

\section{Results and discussion}

\section{Cytotoxicity of the synthesised poly(amidoamine)s}

The poly(amidoamine)s used in this study were synthesised by Michael-type polyaddition (Table 1). P1 and P2 were derived from the structure of ISA1 to modulate the polymer chain flexibility and hydrophobicity. We previously demonstrated that the polymers were cationic at physiological $\mathrm{pH} .{ }^{30}$ Polycations tend to display relatively high cytotoxicity, which often make them unsuitable carriers for macromolecule delivery, especially if a biological function needs to be restored. ${ }^{31,32}$ Ribonuclease A possesses some potential anticancer activity, however cancerous cells are not appropriate model cell lines to evaluate the biocompatibility of nanocarriers, as they are known to display
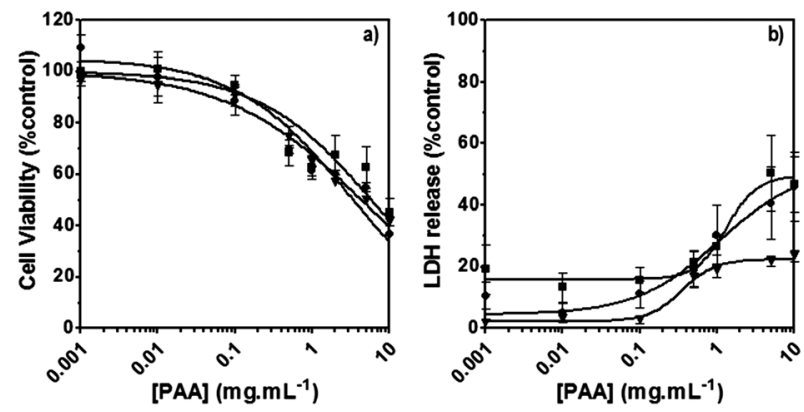

Fig. 1 Cytotoxicity of the synthesised poly(amidoamine)s (ISA1 ( $\mathbf{\nabla})$, P1 ( and P2 ( )) was assessed using HEK293 cells $\left(10^{5}\right.$ cells per well). Panel (a): viability of the cells estimated at $24 \mathrm{~h}$ using an MTS assay. Panel (b): membrane integrity of the cells estimated at $24 \mathrm{~h}$ using an LDH release assay. Mean values \pm SEM, $n=6$.

different sensitivity compare to healthy cells. Therefore, in order to evaluate the potential biocompatibility of the PAAs, the cytotoxicity of the polymers towards non-cancerous cells was evaluated. Their effect on the metabolic activity of HEK293 cells was assessed by measuring the mitochondrial activity after $24 \mathrm{~h}$ incubation. The viability of the cells was concentrationdependent (Fig. 1). The PAAs were not toxic (i.e. viability $>70 \%)^{33}$ up to a concentration of $1 \mathrm{mg} \mathrm{mL}{ }^{-1}$. All $\mathrm{IC}_{50}$ were above $3.5 \mathrm{mg} \mathrm{mL}^{-1}$ (Table 1) which is lower than for polycations such as poly(ethyleneimine ${ }^{32}$ and is similar to what has been reported for other poly(amidoamine)s. ${ }^{21}$ No significant influence of the polymer chemical structures was noticed. P2 seemed to display a lower $\mathrm{IC}_{50}$ value, which may be attributed to the smaller molecular weight for this polymer, however the difference was not significant. Lactate dehydrogenase $(\mathrm{LDH})$ release assay has also been used as a measure of cell viability and gives additional information to mitochondrial activity-based assays. ${ }^{34}$ It can be used to evaluate the integrity of the cell membrane and reflect the damage caused by the polymers. Peng et al. ${ }^{35}$ evaluated the interaction of PAA/DNA polyplexes with bone marrow stromal

Table 1 Physicochemical ${ }^{30}$ and biological properties of the poly(amidoamine)s

Polymers

$M_{\mathrm{w}}$ : weight average molecular weight; $M_{\mathrm{n}}$ : number average molecular weight; PDI: polydispersity index; $\zeta:$ zeta potential. ${ }^{a}$ Mean value of two independent replicates $\pm \mathrm{SEM} ; \mathrm{IC}_{50}$ represents the PAAs concentration at which $50 \%$ of the cell population is dead relative to untreated control cells. $\mathrm{LDH}_{20}$ represents the PAAs concentration at which $20 \%$ of LDH is released relative to control cells treated with triton X100. 
cells and reported low percentage of $\mathrm{LDH}$ release (i.e. $<10 \%$ ) at low N/P ratio. However, polyplexes may display lower cytotoxicity. We measured the $\mathrm{LDH}$ released after $24 \mathrm{~h}$ in presence of the PAAs alone and found it was also concentration-dependent (Fig. 1) with $\mathrm{LDH}_{20}$ above $0.4 \mathrm{mg} \mathrm{mL}{ }^{-1}$ (Table 1). $\mathrm{LDH}_{10}$, the PAAs concentration at which only $10 \%$ of $\mathrm{LDH}$ is released, was determined for P2 $\left(0.09 \mathrm{mg} \mathrm{mL}{ }^{-1}\right)$ and ISA1 $\left(0.28 \mathrm{mg} \mathrm{mL}^{-1}\right)$ indicating the destabilising effect of these two polymers was lower in comparison to P1.

\section{Interaction of the poly(amidoamine)s with RNase A}

Interactions between polyelectrolytes and proteins are generally due to electrostatic forces. ${ }^{36}$ Evidence of complex formation, at physiological $\mathrm{pH}$, between the cationic poly(amidoamine)s and BSA (pI 4.7), an acidic model protein, has been reported. ${ }^{30}$ RNase A is a $13.7 \mathrm{kDa}$ basic protein (pI 9.5). ${ }^{37,38}$ Contrary to $\mathrm{BSA}$, it has an overall cationic charge at physiological $\mathrm{pH}$. The mobility of RNase A in an agarose gel retardation assay was progressively altered with increasing PAA:RNase A weight ratios (Fig. 2) suggesting some complexation despite repulsive forces between the protein and the polyelectrolytes. It is usually considered that complex formation between two macromolecules requires opposite net charges. However, complexation between macromolecules bearing similar net charges (i.e. both anionic or both cationic) has been reported. ${ }^{39-41}$

In general, this has been attributed to the anisotropic distribution of the charges on the protein surface which, depending on the nature of the protein, leads to the formation of either positive or negative "patches". 42 Such "negative patches" have been observed for RNase A using computer modelisation ${ }^{39,43}$ and make binding of the positively charge protein to cationic PAAs possible (Fig. 3). Although Coulombic forces are considered the driving force for protein/polymer interactions, the role of hydrophobicity has also been demonstrated. ${ }^{44,45}$ "Hydrophobic patches" on the surface of RNase A have been identified ${ }^{46,47}$ and could also be involved in its association with the poly(amidoamine)s via hydrophobic interactions (Fig. 3).

The size of the complexes were initially measured at PAA: RNase A 500:1 weight ratio for which full retardation was observed. The results, reported as size distribution by intensity, indicated the presence of a heterogeneous population of polydisperse nanoparticles with some potential aggregation (Fig. 4). Although full retardation of the protein was not achieved at lower weight ratios (Fig. 2), a number of additional peaks in the 10 to $100 \mathrm{~nm}$ range were observed by DLS for all the polymers.
ISAl

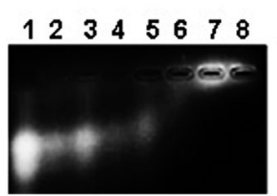

P1

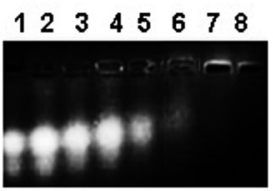

P2

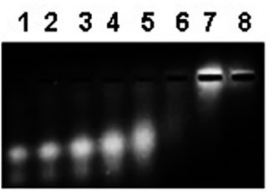

Fig. 2 Complexation of RNase A-OG with the poly(amidoamine)s at different PAA: RNase A weight ratios (w/w). Lane (1) RNase A alone; (2) $10: 1$; (3) $50: 1$; (4) $100: 1$; (5) $200: 1$; (6) $500: 1$; (7) $1000: 1$; (8) $2000: 1$.

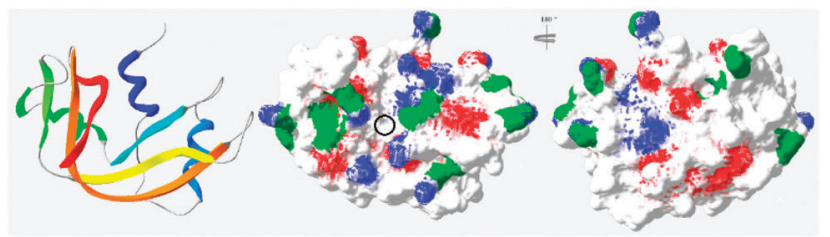

Fig. 3 Ribbon representation of bovine RNase A (PDB: 1kf5) and modelisation of the electrostatic potential and hydrophobic patches. Positive and negative potential patches are represented in blue and red, respectively. Hydrophobic patches are represented in green. The black circle indicates the binding cavity of the protein (see ESI $\dagger$ for 3D animated structure).
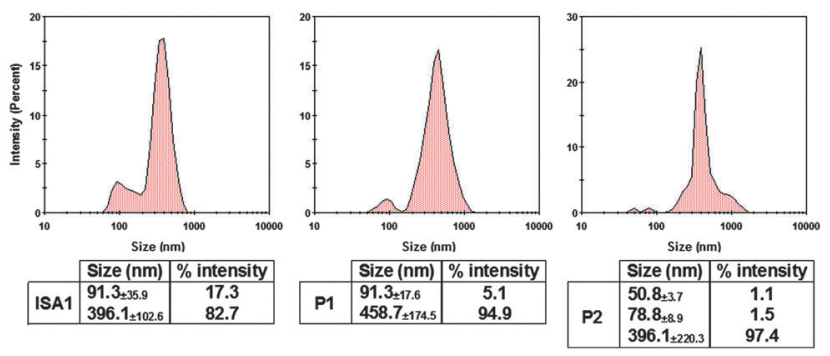

Fig. 4 DLS characterisation of the complexes. [RNase A] $=25 \mu \mathrm{g} \mathrm{m}^{-1}$; PAA: RNase A complexes were prepared at 500:1 (w/w) ratio. Values represent the modal size \pm width of the peak, $n=3$.

These peaks suggested the formation of small complexes and indicated an increase in the heterogeneity of the samples.

The interaction of RNase A with the poly(amidoamine)s was further investigated by microcalorimetry. High sensitivity DSC is generally used to monitor protein thermal unfolding under different experimental conditions. The denaturation temperature at maximum transition $\left(T_{\max }\right)$ is an indicator of the protein thermostability and depends on factors such as the ionic strength or the $\mathrm{pH}$ of the samples. ${ }^{36}$ The higher $T_{\max }$ is, the more stable the protein is. The thermal stability of RNase A has been evaluated in different environments and $T_{\max }$ values ranging from 56.5 to $63.9{ }^{\circ} \mathrm{C}$ have been reported..$^{37,48-50}$ Under our experimental conditions, $T_{\max }$ was measured at $63.3{ }^{\circ} \mathrm{C}$ (Fig. 5 and Table 2) with a corresponding unfolding enthalpy of $382.3 \mathrm{~kJ} \mathrm{~mol}^{-1}$. DSC can also be used to investigate the thermal denaturation of proteins in complexes. While some studies have demonstrated that polymers can promote or maintain the thermal stability of model proteins, ${ }^{51,52}$ others have reported a destabilisation effect. ${ }^{36,53,54}$ Glycosylation, trimethylamine
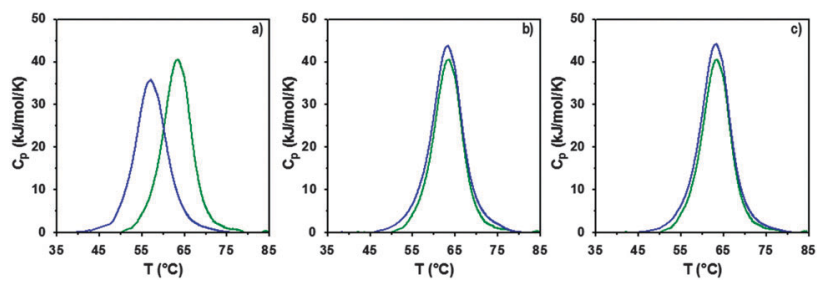

Fig. 5 DSC profiles following normalisation and baseline correction of RNase A alone (green) and in the presence (blue) of (a) ISA1; (b) P1 or (c) P2. Heating rate $1{ }^{\circ} \mathrm{C} \mathrm{min}{ }^{-1}$; [RNase $\left.A\right]=0.5 \mathrm{mg} \mathrm{mL}^{-1}$; PAA: RNase $A$ complexes were prepared at ratio $10: 1(\mathrm{w} / \mathrm{w})$. 
Table 2 Thermodynamic properties of RNase A in the absence and presence of the PAAs

\begin{tabular}{|c|c|c|c|c|c|c|}
\hline & $T_{\max }\left({ }^{\circ} \mathrm{C}\right)$ & $\Delta H_{\text {cal }}\left(\mathrm{kJ} \mathrm{mol}^{-1}\right)$ & $\Delta S_{\text {cal }}\left(\mathrm{kJ} \mathrm{mol}^{-1} \mathrm{~K}^{-1}\right)$ & $\mathrm{d} H_{\mathrm{V}}\left(\mathrm{kJ} \mathrm{mol}^{-1}\right)$ & $n$ & $\Delta T\left({ }^{\circ} \mathrm{C}\right)$ \\
\hline RNase A & $63.32_{ \pm 0.02}$ & $382.3_{ \pm 30.3}$ & $1.14_{ \pm 0.09}$ & $396.6_{ \pm 11.8}$ & $1.04_{ \pm 0.05}$ & $7.5_{ \pm 0.2}$ \\
\hline P1 : RNase A & $63.11_{ \pm 0.02}$ & $426.7_{ \pm 7.9}$ & $1.27_{ \pm 0.02}$ & $408.1_{ \pm 4.5}$ & $0.96_{ \pm 0.01}$ & $7.9_{ \pm 0.0}$ \\
\hline P2: RNase A & $63.13_{ \pm 0.00}$ & $419.1_{ \pm 5.7}$ & $1.25_{ \pm 0.02}$ & $404.6_{ \pm 1.4}$ & $0.97_{ \pm 0.02}$ & $7.6_{ \pm 0.3}$ \\
\hline ISA1 : RNase A & $56.81_{ \pm 0.12}$ & $353.5_{ \pm 16.2}$ & $1.07_{ \pm 0.05}$ & $363.6_{ \pm 6.3}$ & $1.03_{ \pm 0.03}$ & $8.2_{ \pm 0.0}$ \\
\hline
\end{tabular}

$\mathrm{T}_{\max }$ : temperature of denaturation. $\mathrm{T}_{\max }$ was determined as the temperature corresponding to the maximum heat capacity $\left(C_{\mathrm{p}}\right) ; \Delta H_{\text {cal }}:$ calorimetric enthalpy change; $\Delta S_{\text {cal }}$ : calorimetric entropy change; $\mathrm{d} H_{\mathrm{V}}$ : Van't Hoff enthalpy change; $n$ : cooperative units; $\Delta T$ : width at half maximum. Mean value of two independent replicates \pm SEM.

$N$-oxide (TMAO) and lipids ${ }^{48,50,55}$ have improved the thermal stability of RNase A to different extent, whereas complexation with polyanions such as heparin or adsorption on silica nanoparticle had essentially a negative effect. ${ }^{37,38}$

In a previous study, we demonstrated that $\mathrm{P} 1$ and $\mathrm{P} 2$ could stabilise BSA, whereas ISA1 had an adverse effect. ${ }^{30}$ The influence of the poly(amidoamine)s on the thermal stability of RNase A, was investigated under similar conditions (Fig. 5). The temperature at maximum transition for RNase A, decreased by $6.5{ }^{\circ} \mathrm{C}$ in the presence of ISA1 (Table 2). This is similar to what we previously observed with BSA, although in the case of RNase A the width of the peak at half maximum transition $(\Delta T)$ remained constant, suggesting no intermediate in the unfolding process. ${ }^{37}$ On the contrary, $T_{\max }$ was not affected in the presence of P1 or P2 indicating RNase A maintained its thermal stability (Table 2). We previously found that P1 and P2 displayed increased chain flexibility in comparison to ISA1. ${ }^{30}$ The increased rigidity of the polymer backbone could potentially explain that under similar experimental conditions, ISA1 destabilises the protein. Further analysis of all the thermograms assuming a two-state model of denaturation (Native protein $\leftrightarrows$ Unfolded protein), demonstrated the equivalence of the calorimetric and Van't Hoff enthalpies, which further confirmed the absence of intermediate. This also indicated some cooperativity in the unfolding process of RNase A (i.e. $n=\mathrm{d} H_{\mathrm{v}} / \Delta H_{\text {cal }} \sim 1$ ) and has been previously observed for the native protein or in presence of TMAO and lipids. ${ }^{48,50}$

Complex formation between cationic poly(amidoamine)s and an acidic protein revealed that in some cases, the activity of the protein could be inhibited. ${ }^{24}$ We therefore assessed whether the enzymatic activity of RNase A would be altered upon interaction and complexation with our poly(amidoamine)s (Fig. 6). Yeast RNA was incubated for $30 \mathrm{~min}$. at $37{ }^{\circ} \mathrm{C}$ in the presence or absence of RNase A. The enzyme was able to degrade the ribonucleic acids in the absence or in the presence of the poly(amidoamine)s, even at higher ratio corresponding to full

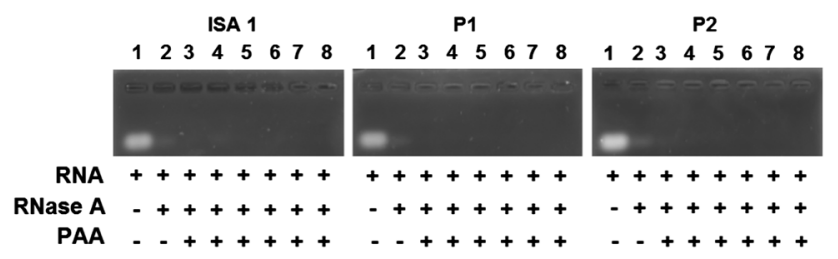

Fig. 6 Enzymatic activity of RNase $A$ in the absence or presence of poly(amidoamine)s. Lane (1) RNA alone; (2) RNA + RNase A; Lanes (3-8) RNA + PAA : RNase A at different weight ratios: (3) $1: 1$; (4) $5: 1$; (5) $10: 1$; (6) $50: 1$; (7) $100: 1$; (8) $500: 1$. complexation of the protein (Fig. 2) indicating the catalytic site of RNase A was accessible to the substrate.

\section{Cellular uptake and cytotoxicity of RNase A}

Ribonucleases capable to reach cellular ribonucleic acids are known to induce cell death. ${ }^{2}$ Although the intracellular pathway of RNase A is still subject to discussion, some aspects have been identified. ${ }^{56}$ However, following interaction with the cell membrane and endocytosis, only a small amount of RNase A reaches the cytosol where it eventually binds the ribonuclease inhibitor (RI). ${ }^{57}$ After binding, the catalytic activity of RNase A is totally inhibited due to obstruction of its active site, hence eliminating any cytotoxic effect. B16F1 cells were initially subjected to increasing concentration $\left(0-100 \mu \mathrm{g} \mathrm{mL}^{-1}\right)$ of wild-type RNase A. As expected, no effect on the viability of the cells was observed (Fig. 7c - red line). Aside from direct cytosolic injection, ${ }^{9,10}$
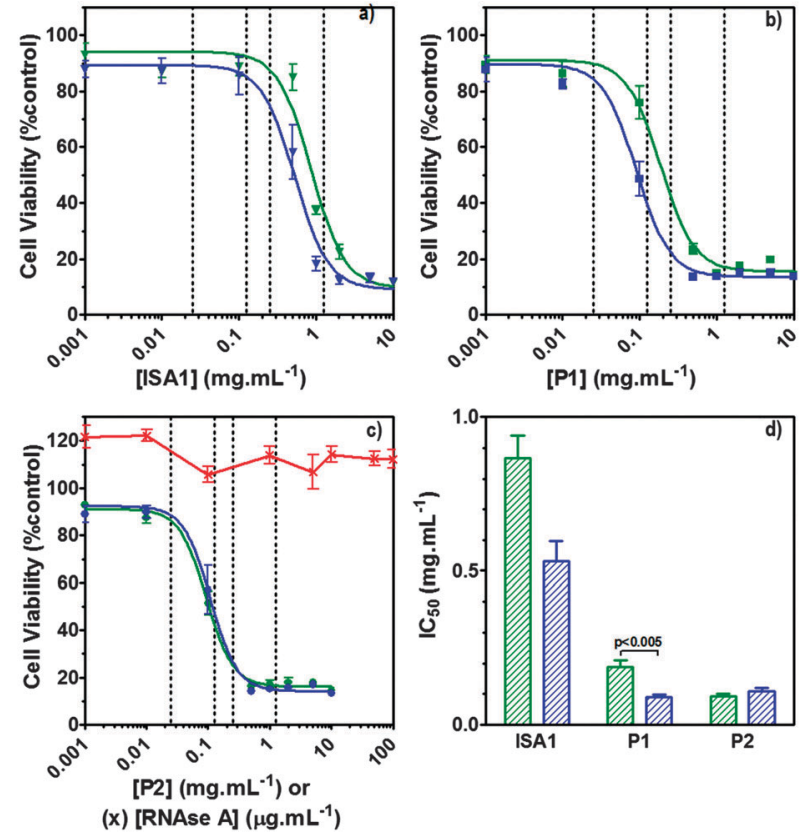

Fig. 7 Intracellular delivery and cytotoxicity of RNase A. Panels (a), (b) and (c) show the viability of B16F1 cells $\left(10^{4}\right.$ cells per well) at $48 \mathrm{~h}$ following $5 \mathrm{~h}$ incubation with poly(amidoamine)s ISA1 (a), P1 (b) and P2 (c) in the absence (green) or presence (blue) of a non-toxic concentration of RNase A $\left(25 \mu \mathrm{g} \mathrm{mL}^{-1}\right.$ ). Panel (d) shows the corresponding $\mathrm{IC}_{50}$ in the absence (green) or presence (blue) of RNase $A ; C_{50}$ values were determined by nonlinear regression using a sigmoidal dose-response curve (eqn (2)) (goodness of fit, $R^{2}>0.9$ for all fits). Panel (c) also shows the viability of B16F1 with increasing concentration of RNase A (red). Mean values \pm SEM, $n=6$. 
most approaches to improve the efficiency of RNase A have involved the development of RI evasive mutant proteins. ${ }^{57}$ However, a few techniques involving the chemical derivatisation of RNase A, including cationisation, have been used with varied success. ${ }^{15-20}$ More recently, an alternative method has been developed to co-incubate RNase A with PAMAM dendrimers ${ }^{58}$ but under the experimental conditions reported, only RNase A variants were successfully delivered. Poly(amidoamine)s are endosomolytic polymers and have been used to promote the intracellular delivery of macromolecular drugs such as plasmid DNA, siRNA and proteins. ${ }^{21,22}$ RNase A exerts its cytotoxicity by cleavage of cytosolic RNA, which requires escape from the endosomes to the cytosol.

Hence, to assess the ability of the synthesised linear poly(amidoamine)s to deliver RNase A inside the cytosol, B16F1 cells were incubated for $5 \mathrm{~h}$ with the polymers alone or the complexes. The complexes were prepared using a non-toxic concentration of RNase A and different PAA: RNase A weight ratios. Following removal of the complexes, the cell viability was assessed at $43 \mathrm{~h}$ post-transfection using an MTS assay. Concentrations of 5 and $10 \mu \mathrm{g} \mathrm{mL}^{-1}$ of RNase A were initially used but no effect was observed (data not shown). The concentration was increased to $25 \mu \mathrm{g} \mathrm{mL}{ }^{-1}$ (Fig. 7). Comparison of the $\mathrm{IC}_{50}$ values obtained for the polymers alone and the complexes demonstrated that for P2 no increase in cytotoxicity was observed (Fig. 7c and d). ISA1, which has been previously used to deliver non-permeant proteins, ${ }^{27-29}$ seemed to be more efficient as a decrease of the $\mathrm{IC}_{50}$ was noticed for the complexes (Fig. 7a and d). However, the difference was considered not significant $(p>0.005)$. P1 was the only poly(amidoamine) able to induce efficient intracellular release of RNase A, as indicated by a significant two-fold increase of the complexes cytotoxicity $\left(\mathrm{IC}_{50}=0.09 \mathrm{mg} \mathrm{mL}{ }^{-1} ; p<0.005\right.$ ) (Fig. 7b and d). To further investigate the cellular delivery of wild-type RNase A by the PAAs, we used a protein labelled with oregon green (OG) and incubated the B16F1 cells with complexes prepared at different PAA/RNase A-OG weight ratios (RNase A-OG: $25 \mu \mathrm{g} \mathrm{mL}^{-1}$ ), selected to match different sections of the dose-response curves (Fig. 7a-c - vertical dotted black lines). The cell associated fluorescence $(\mathrm{CaF})$ at $37{ }^{\circ} \mathrm{C}$ was quantified after $5 \mathrm{~h}$ using flow cytometry (Fig. 8). At this temperature, the observed fluorescence corresponded to the fraction of protein taken up by the cell via endocytosis but also to the protein simply adsorbed on the external surface of the cell membrane. This latter non-specific binding (NSB) can be estimated by reducing the metabolic activity of the cells at low temperature, inhibiting endocytosis. ${ }^{59,60}$ NSB was quantified at $4{ }^{\circ} \mathrm{C}$ and was subsequently subtracted to determine the total uptake of the protein at $37{ }^{\circ} \mathrm{C}^{22}$ All the polymers promoted increased delivery of the protein at all ratios. Uptake of the protein increased with the proportion of PAA levelling off at higher ratios, perhaps indicating some saturation of the intracellular pathway.

The use of wild-type RNase A as a potential therapeutic agent has been essentially impaired due to its inefficient intracellular delivery and inhibition by the RI. ${ }^{2}$ However, some studies have recently demonstrated that RI evasion might not be the only
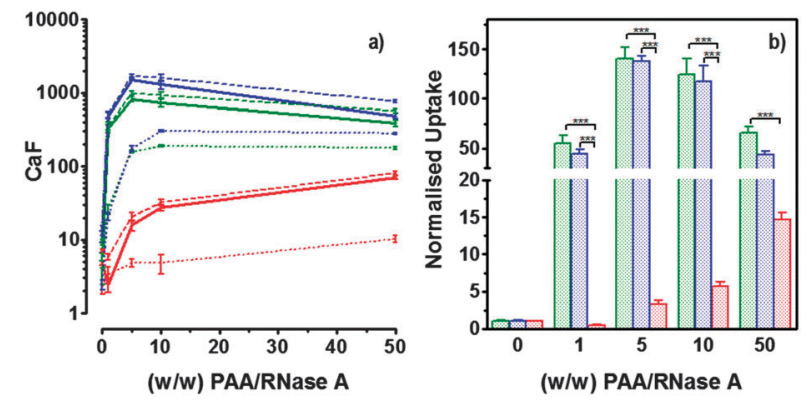

Fig. 8 Cellular uptake of fluorescently labelled RNase $A\left(25 \mu \mathrm{g} \mathrm{mL}^{-1}\right)$ at several PAA/RNase A (w/w) ratios: ISA1 (red), P1 (green) and P2 (blue). Panel (a) shows the B16F1 $\left(10^{5}\right.$ cells per well) cell associated fluorescence at $37{ }^{\circ} \mathrm{C}$ (dashed lines) and $4{ }^{\circ} \mathrm{C}$ (dotted lines) after $5 \mathrm{~h}$ incubation. Total uptake at $37{ }^{\circ} \mathrm{C}$ (plain lines) was calculated by subtracting values at $4{ }^{\circ} \mathrm{C}$. Panel (b) shows the total uptake at $37{ }^{\circ} \mathrm{C}$ normalised to the uptake of RNase $\mathrm{A}$ alone. Mean values $\pm \mathrm{SEM}, n=6$, *** $p<0.001$.

prerequisite to induce some cytotoxicity, improving translocation of the protein into the cytosol after endocytosis could be sufficient to saturate the RI. ${ }^{11,12}$ Although, P2 was able to promote cellular uptake of the protein to similar level as P1 (Fig. 8) we did not observe any increased toxicity for the delivery of RNase A with this polymer (Fig. 7c). The mechanism by which poly(amidoamine)s can promote macromolecule translocation into the cytosol of the cells has not been fully elucidated. However, it is generally considered that the buffer capacity of the polymer is an important factor. ${ }^{21}$ The "proton sponge effect" is the current standard theory to explain the endosomolytic properties of most polycations. ${ }^{61}$ The hypothesis relies on the buffer capacity of the polymers, higher buffer capacity corresponding to higher transfection efficiency. P2 displayed a lower buffer capacity in comparison to both P1 and ISA1, ${ }^{30}$ this seems to have impaired its endosomolytic capacity and potentially limited the cytoplasmic translocation of RNase A. On the contrary, the efficiency of ISA1 seemed to be limited not by its buffer capacity, similar to P1, but by its ability to promote cellular uptake significantly lower than both P1 and P2 (Fig. 8b). The amount of protein reaching the cytosol may not have been appropriate to saturate the RI to a significant extend. The results observed in the presence of P1 indicated sufficient amount of RNase A was delivered into the cytosol of the B16F1 cells to increase cell death (Fig. 7b). However, at the ratios for which the effect is observed, a population of complexes co-exist with free protein. It is therefore likely that the intracellular delivery taking place is promoted by both complexation with $\mathrm{P} 1$ and the effect of the polymer and/or complexes "in trans". Overall, our results indicate that a minimum concentration of RNase A was required to observe an effect and correlate with previous observations indicating that provided the appropriate amount of RNase A reaches the cytosol, the RI could be saturated. ${ }^{11,12}$

\section{Experimental}

\section{Materials}

RNase A from bovine pancreas, $\mathrm{NaCl}$ and triton $\mathrm{X}-100$ were from Sigma (Gillingham, UK). TRIS buffer, nicotinamide adenine 
dinucleotide (NAD), HEPES, D-glucose, DMSO, HCl, phenazine methosulfate (PMS) and TAE were from Fisher (Loughborough, UK). Sodium-L-lactate was from Alfa Aesar (Heysham, UK). Iodonitrotetrazolium salt (INT) was from TCI (Zwijndrecht, Belgium). Agarose was from Roche (Burgess Hill, UK). DMEM, RPMI-1640, DPBS, FBS, penicillin/streptomycin/glutamine (PSG), minimum essential medium non-essential amino acids (MEM NEAA) and succinimidyl ester oregon green 488 (OG) were from Life Technologies (Paisley, UK). 3-(4,5-Dimethylthiazol-2-yl)-5(3-carboxymethoxyphenyl)-2-(4-sulfophenyl)-2 $\mathrm{H}$-tetrazolium (MTS) was from Promega (Mannheim, Germany). Mouse melanoma (B16F1) and human embryonic Kidney 293 (HEK293) cells were from the European Collection of Cell Cultures. The synthesis and physicochemical characterisation of the poly(amidoamine)s (P1: poly[ $\left[N, N^{\prime}\right.$-ethylenebisacrylamide)-co-( $N, N^{\prime}$-bis(acryloyl)piperazine)-co-(4-amino-1-butanol)]; P2: poly[( $N, N^{\prime}$-ethylenebisacrylamide)-co-( $N, N^{\prime}$-bis(acryloyl)piperazine)-co-(5-amino-1-pentanol)] and ISA1: poly[( $N, N^{\prime}$-bis(acryloyl)piperazine)-co-(2-methylpiperazine)-co-( $N, N^{\prime}$-bis(2-hydroxyethyl)ethylenediamine)]) have been reported elsewhere. ${ }^{30}$

\section{Methods}

Agarose gel retardation assay. Samples of PAA : RNase A-OG were prepared by mixing $18.7 \mu \mathrm{L}$ of PAAs $\left(2.4-480 \mathrm{mg} \mathrm{mL}^{-1}\right.$ in $10 \mathrm{mM}$ HEPES, $\mathrm{pH}=7.4,5 \mathrm{wt} \%$ D-glucose) with $3.8 \mu \mathrm{L}$ of RNase A-OG $\left(1.18 \mathrm{mg} \mathrm{mL}^{-1}\right)$. The mixtures were left at room temperature (r.t.) for $30 \mathrm{~min}$. and $21.5 \mu \mathrm{L}$ of HEPES buffer was added. Samples were applied onto a $0.7 \%(\mathrm{w} / \mathrm{v})$ agarose gel. Electrophoresis was run at $60 \mathrm{~V}$ for $45 \mathrm{~min}$. in a $1 \times$ TAE buffer. RNase A-OG was visualised using a G:BOX transilluminator (Syngene). Free protein was used as a control. [Oregon green (OG) labelling of RNase A (RNase A-OG) was carried out according to Life Technologies protocol (degree of labelling found: $0.33 \mathrm{~mol} \mathrm{OG} \mathrm{mol}^{-1}$ RNase A). No free dye was detected following thorough purification by PD10 column and ultracentrifugation (MWCO $3 \mathrm{kDa}$ )].

High sensitivity differential scanning calorimetry. Thermal stability of RNase A was determined using a Nano DSC microcalorimeter (TA Instruments) equipped with capillary cells $(300 \mu \mathrm{L})$. PAA: RNase A samples at ratio 10:1 (w/w) were prepared by mixing RNase A $\left(400 \mu \mathrm{L}, 2.5 \mathrm{mg} \mathrm{mL}{ }^{-1}, 10 \mathrm{mM}\right.$ HEPES $\mathrm{pH}=7.4,0.15 \mathrm{M} \mathrm{NaCl}$ ) with appropriate PAA solutions (1.6 mL, $6.25 \mathrm{mg} \mathrm{mL}^{-1}, 10 \mathrm{mM}$ HEPES pH 7.4, 0.15 M NaCl). Final concentration of RNase A was $0.5 \mathrm{mg} \mathrm{mL}^{-1}$. The samples were left at room temperature for $30 \mathrm{~min}$. and were degassed for $10 \mathrm{~min}$., at $10{ }^{\circ} \mathrm{C}$ and under vacuum $(23 \mathrm{mmHg})$. During the analysis, a pressure of $4 \mathrm{~atm}$ was applied over the reference and sample cells. Thermograms were recorded from $10{ }^{\circ} \mathrm{C}$ to $100{ }^{\circ} \mathrm{C}$ with a scanning rate of $1{ }^{\circ} \mathrm{C} \mathrm{min}^{-1}$. Data were analysed using the Launch Nanoanalyze software from TA Instrument. No thermal transition were detected for the PAAs alone. ${ }^{30}$

Dynamic light scattering. Measurements were carried out at $25{ }^{\circ} \mathrm{C}$ using a nanozS zetasizer (Malvern). Complexes were prepared as previously described at PAA: RNase A (w/w) ratios from 10:1 to 500:1 with an RNase final concentration of $25 \mu \mathrm{g} \mathrm{mL} L^{-1}$. In order to increase the resolution of the peak observed, the analysis of the results was carried out using narrow mode.

Enzymatic activity. Complexes $(11 \mu \mathrm{L})$ were prepared as previously described at PAA: RNase A (w/w) ratios from $1: 1$ to 500 : 1 using $40 \mathrm{ng}$ of RNase A. The mixtures were left at r.t. for $30 \mathrm{~min} .4 \mu \mathrm{g}$ of RNA $\left(5 \mu \mathrm{L}, 0.8 \mathrm{mg} \mathrm{mL}^{-1}\right)$ were added and the samples were further incubated for $30 \mathrm{~min}$. at $37{ }^{\circ} \mathrm{C}$. Samples were then applied onto a $1 \%(\mathrm{w} / \mathrm{v})$ agarose gel. Electrophoresis was run at $40 \mathrm{~V}$ for $30 \mathrm{~min}$. in a $1 \times$ TAE buffer. The gels were stained for $30 \mathrm{~min}$. in $200 \mathrm{~mL}$ of $1 \times$ TAE buffer containing ethidium bromide $\left(0.5 \mu \mathrm{g} \mathrm{mL}^{-1}\right)$ and visualised using the transilluminator.

Cells and culture conditions. HEK293 cells were cultured in DMEM supplemented with $10 \%$ FBS, $1 \times$ PSG and $1 \times$ MEM NEAA. B16F1 cells were cultured in RPMI supplemented with $10 \%$ FBS and $1 \times$ PSG. All cells were maintained in a humidified $5 \% \mathrm{CO}_{2}$-containing atmosphere at $37{ }^{\circ} \mathrm{C}$ and passaged when reaching $80 \%$ confluence.

Cytotoxicity of the PAAs. HEK293 cells $\left(10^{5}\right.$ cells per well) were seeded in 96-well plates. After $24 \mathrm{~h}$, the medium was replaced by filtered $(0.2 \mu \mathrm{m})$ polymer solutions $(100 \mu \mathrm{L}$; 0-20 mg mL $\left.{ }^{-1}\right)$ and fresh medium $(100 \mu \mathrm{L})$. MTS assay: After $21 \mathrm{~h}$ incubation, PAAs solutions were removed and fresh medium without FBS was added $(200 \mu \mathrm{L})$. MTS : PMS reagent (20 $\mu \mathrm{L} ; 2: 0.92 \mathrm{mg} \mathrm{mL}^{-1}$ in DPBS) was added and cells were left at $37{ }^{\circ} \mathrm{C}$ for $3 \mathrm{~h}$. Absorbance was read at $492 \mathrm{~nm}$. Viability was expressed as percentage of untreated control cells. $\mathrm{IC}_{50}$ values were determined graphically. $\mathrm{LDH}$ release assay: After $24 \mathrm{~h}$ incubation, the cells were centrifuged at $1000 \mathrm{rpm}$ for $5 \mathrm{~min}$. and $100 \mu \mathrm{L}$ of the supernatant was transferred to clean 96-well plates. $90 \mu \mathrm{L}$ of fresh reagent I and $10 \mu \mathrm{L}$ of fresh reagent II were sequentially added to each well [reagent I: sodium-Llactate $(800 \mu \mathrm{L} ; 0.54 \mathrm{mM}), \mathrm{NAD}(800 \mu \mathrm{L} ; 1.30 \mathrm{mM})$ diluted into $5.6 \mathrm{~mL}$ TRIS buffer $(0.2 \mathrm{M}) \mathrm{pH}=8.2$; reagent II: INT in DMSO ( $1 \mathrm{~mL} ; 66 \mathrm{mM})$ and PMS in TRIS buffer $(1 \mathrm{~mL} ; 28 \mathrm{mM})]$. The plates were incubated for $30 \mathrm{~min}$. in the dark and at room temperature. The reaction was stopped by adding $15 \mu \mathrm{L}$ of $\mathrm{HCl}$ (1 M). Absorbance was read at $492 \mathrm{~nm}$. LDH release was expressed as percentage release (1) relative to control cells treated with $2 \%$ triton $\mathrm{X}(\mathrm{TX})$ and $\mathrm{LDH}_{20 / 10}$ values were determined graphically.

$$
\%=\frac{\mathrm{A}-\mathrm{A}_{\text {untreated cells }}}{\mathrm{A}_{\mathrm{TX} \text { treated cells }}-\mathrm{A}_{\text {untreated cells }}} \times 100
$$

Cytotoxicity of RNase A. B16F1 cells $\left(10^{4}\right.$ cells per well) were seeded in 96-well plates. After $24 \mathrm{~h}$, the medium was replaced by fresh medium $(100 \mu \mathrm{L}) .100 \mu \mathrm{L}$ of filtered $(0.2 \mu \mathrm{m})$ RNase $\mathrm{A}$ solutions $\left(0.2 \mathrm{ng} \mathrm{mL}^{-1}-200 \mu \mathrm{g} \mathrm{mL}^{-1}\right)$ or polymer solutions (0-40 $\mathrm{mg} \mathrm{mL}^{-1}$ ) without or incubated with RNase A (30 min. at r.t.; $25 \mu \mathrm{g} \mathrm{mL}{ }^{-1}$ final concentration) were added to the cells. After $5 \mathrm{~h}$ of incubation at $37^{\circ} \mathrm{C}$, the solutions were removed and fresh medium $(200 \mu \mathrm{L})$ was added. Following a further $40 \mathrm{~h}$, an MTS assay was carried out as described above. $\mathrm{IC}_{50}$ values were determined by nonlinear regression using a sigmoidal doseresponse curve and eqn (2) with a slope $h=-2$ as a constraint 
(goodness of fit, $R^{2}>0.9$ for all fits). Data represent mean value of two independent experiments with triplicates and were further analysed using an unpaired t-test to calculate two-tailed $\mathrm{p}$ values with a confidence of interval set as $99 \% . \mathrm{IC}_{50}$ were considered significantly different if $p<0.005$ (GraphPad Prism).

$$
Y=B+\frac{(T-B)}{1+10^{\left(\left(\log \mathrm{EC}_{50}-X\right) \times h\right)}}
$$

where $B$ and $T$ are the bottom and the top of the curve, respectively and $h$ the Hill slope.

Cellular uptake. B16F1 cells $\left(10^{5}\right.$ cells per well) were seeded in 24-well plates. After $24 \mathrm{~h}$, the medium was replaced $(200 \mu \mathrm{L})$ and $200 \mu \mathrm{L}$ of PAA: RNase A-OG complexes $(1: 1$ to $50: 1(\mathrm{w} / \mathrm{w})$ ratios; $25 \mu \mathrm{g} \mathrm{mL}{ }^{-1}$ RNase A-OG final concentration) were added. The cells were incubated at $37{ }^{\circ} \mathrm{C}$ for $5 \mathrm{~h}$, rinsed with ice-cold PBS and recovered by trypsinisation. The samples were then centrifuged for $3 \mathrm{~min}$ at $800 \mathrm{~g}$. The supernatant was removed and the cells suspended in ice-cold PBS $(300 \mu \mathrm{L})$ for analysis by flow cytometry. For each sample 10000 events were acquired, untreated cells were used as reference and RNase A-OG and polymer solutions were used as control. The same experiments were also conducted at $4{ }^{\circ} \mathrm{C}$ in which case the cells were left at $4{ }^{\circ} \mathrm{C}$ for $1 \mathrm{~h}$ prior addition of the complexes. The cellular uptake was calculated using eqn (3).

$$
\text { Uptake }=(\mathrm{CaF})_{37^{\circ} \mathrm{C}}-(\mathrm{CaF})_{4^{\circ} \mathrm{C}}
$$

where CaF represents the cell associated fluorescence at $37^{\circ} \mathrm{C}$ or $4{ }^{\circ} \mathrm{C}$ calculated as previously described. ${ }^{22}$

Protein surface modelling. Modelisations were carried out using the Swiss-Pdb viewer (v4.1.0). Coordinates for RNase A were those deposited in the Protein Data Bank (PDB) as data set "1KF5". 62 The electrostatic potential surrounding RNase A was calculated by the Poisson-Boltzmann equation using a dielectric constants of 2 for the protein interior, 80 for the solvent region and an ionic strength of $0.15 \mathrm{mM}$.

\section{Conclusions}

We demonstrated the ability of linear cationic poly(amidoamine)s ISA1, P1 and P2 $(\zeta=+26.6$ to $+27.6 \mathrm{mV}$ at $\mathrm{pH} 7.4)$ to interact with RNase A on the "wrong side" of the isoelectric point due to the presence of "negative patches" on the surface of the protein at physiological $\mathrm{pH}$. Upon interaction, a heterogeneous population of nanocomplexes (10 to $100 \mathrm{~nm}$ ) were observed. Microcalorimetry further indicated that at PAA: RNase A - 10:1 (w/w) ratio, $\mathrm{P} 1$ and P2 did not destabilise RNase A whereas ISA1 did. Upon $24 \mathrm{~h}$ incubation all the PAAs displayed low cytotoxicity towards non-cancerous cells $\left(\mathrm{IC}_{50}=3.5\right.$ to $6 \mathrm{mg} \mathrm{mL}{ }^{-1} ; \mathrm{LDH}_{20}=0.5$ to $1 \mathrm{mg} \mathrm{mL}^{-1}$ ). Free wild-type RNase A was not toxic to B16F1 cells up to a concentration of $100 \mu \mathrm{g} \mathrm{mL}{ }^{-1}$. However, when complexed with P1, increased cytotoxicity and cellular uptake was observed indicating that P1 was able to promote intracellular delivery of biologically active $\mathrm{RNase} \mathrm{A}\left(\mathrm{IC}_{50}=0.09 \mathrm{mg} \mathrm{mL} \mathrm{m}^{-1}\right)$ and potentially helped to bypass or overpower the inhibitory action of the RI found in the cytosol of most cells.

\section{Acknowledgements}

We would like to thank the Medway School of Pharmacy for financial support and Pr. B. Chowdhry (University of Greenwich) for providing access to the HSDSC.

\section{References}

1 L. Ledoux, Nature, 1955, 176, 36-37.

2 A. W. Nicholson, Ribonucleases, Springer, Berlin Heidelberg, 2011.

3 C. Ercole, R. A. Colamarino, E. Pizzo, F. Fogolari, R. Spadaccini and D. Picone, Biopolymers, 2009, 91, 1009-1017.

4 J. E. Lee and R. T. Raines, Biochemistry, 2005, 44, 15760-15767.

5 A. Di Donato, V. Cafaro and G. D'Alessio, J. Biol. Chem., 1994, 269, 17394-17396.

6 V. Cafaro, A. Bracale, A. Di Maro, S. Sorrentino, G. D’Alessio and A. Di Donato, FEBS Lett., 1998, 437, 149-152.

7 P. Pouckova, M. Morbio, F. Vottariello, D. V. Laurents, J. Matousek, J. Soucek, G. Gotte, M. Donadelli, C. Costanzo and M. Libonati, Bioconjugate Chem., 2007, 18, 1946-1955.

8 F. Vottariello, C. Costanzo, G. Gotte and M. Libonati, Bioconjugate Chem., 2010, 21, 635-645.

9 S. K. Saxena, S. M. Rybak, G. Winkler, H. M. Meade, P. Mcgray, R. J. Youle and E. J. Ackerman, J. Biol. Chem., 1991, 266, 21208-21214.

10 M. R. Smith, D. L. Newton, S. M. Mikulski and S. M. Rybak, Exp. Cell Res., 1999, 247, 220-232.

11 F. Leich, N. Stohr, A. Rietz, R. Ulbrich-Hofmann and U. Arnold, J. Biol. Chem., 2007, 282, 27640-27646.

12 C. De Lorenzo, C. Di Malta, G. Cali, F. Troise, L. Nitsch and G. D’Alessio, FEBS Lett., 2007, 581, 296-300.

13 D. Wang and S. Moore, Biochemistry, 1977, 16, 2937-2942.

14 J. Futami, E. Nukui, T. Maeda, M. Kosaka, H. Tada, M. Seno and H. Yamada, J. Biochem., 2002, 132, 223-228.

15 J. Futami, T. Maeda, M. Kitazoe, E. Nukui, H. Tada, M. Seno, M. Kosaka and H. Yamada, Biochemistry, 2001, 40, 7518-7524.

16 J. Futami, M. Kitazoe, T. Maeda, E. Nukui, M. Sakaguchi, J. Kosaka, M. Miyazaki, M. Kosaka, H. Tada, M. Seno, Y. Sasaki, N. H. Huh, M. Namba and H. Yamada, J. Biosci. Bioeng., 2005, 99, 95-103.

17 J. Zhang, J. Du, M. Yan, A. Dhaliwal, J. Wen, F. Liu, T. Segura and Y. Lu, Nano Res., 2011, 4, 425-433.

18 J. Matousek, P. Pouckova, J. Soucek and J. Skvor, J. Controlled Release, 2002, 82, 29-37.

19 P. Pouckova, M. Zadinova, D. Hlouskova, J. Strohalm, D. Plocova, M. Spunda, T. Olejar, M. Zitko, J. Matousek, K. Ulbrich and J. Soucek, J. Controlled Release, 2004, 95, 83-92.

20 S. X. Liu, L. J. Sun, J. Wang, G. H. Ma, Z. G. Su and T. Hu, Process Biochem., 2012, 47, 1364-1370.

21 P. Ferruti, J. Polym. Sci., Part A: Polym. Chem., 2013, 51, 2319-2353.

22 S. C. W. Richardson, N. G. Pattrick, N. Lavignac, P. Ferruti and R. Duncan, J. Controlled Release, 2010, 142, 78-88. 
23 N. Lavignac, J. L. Nicholls, P. Ferruti and R. Duncan, Macromol. Biosci., 2009, 9, 480-487.

24 G. Coué and J. F. J. Engbersen, J. Controlled Release, 2011, 152, 90-98.

25 S. Cohen, G. Coué, D. Beno, R. Korenstein and J. F. J. Engbersen, Biomaterials, 2012, 33, 614-623.

26 G. Coué, C. Freese, R. E. Unger, C. J. Kirkpatrick and J. F. J. Engbersen, Acta Biomater., 2013, 9, 6062-6074.

27 N. G. Pattrick, S. C. W. Richardson, M. Casolaro, P. Ferruti and R. Duncan, J. Controlled Release, 2001, 77, 225-232.

28 N. Lavignac, M. Lazenby, P. Foka, B. Malgesini, I. Verpilio, P. Ferruti and R. Duncan, Macromol. Biosci., 2004, 4, 922-929.

29 N. Lavignac, M. Lazenby, J. Franchini, P. Ferruti and R. Duncan, Int. J. Pharm., 2005, 300, 102-112.

30 J. L. N. Dubois and N. Lavignac, Polym. Chem., 2014, 5, 1586-1592.

31 A. C. Hunter, Adv. Drug Delivery Rev., 2006, 58, 1523-1531.

32 L. Parhamifar, A. K. Larsen, A. C. Hunter, T. L. Andresen and S. M. Moghimi, Soft Matter, 2010, 6, 4001-4009.

33 International Organization for Standardization, ISO 109935:2009(E), Biological evaluation of medical devices Part 5: Tests for in vitro cytotoxicity, Switzerland. 2009.

34 L. Parhamifar, H. Andersen and S. M. Moghimi, Methods Mol. Biol., 2013, 948, 13-22.

35 L. Peng, Y. Gao, Y.-N. Xue, S.-W. Huang and R.-X. Zhuo, Biomaterials, 2010, 31, 4467-4476.

36 M. Karayianni, S. Pispas, G. D. Chryssikos, V. Gionis, S. Giatrellis and G. Nounesis, Biomacromolecules, 2011, 12, 1697-1706.

37 H. Larsericsdotter, S. Oscarsson and J. Buijs, J. Colloid Interface Sci., 2001, 237, 98-103.

38 E. Sedlak, D. Fedunova, V. Vesela, D. Sedlakova and M. Antalik, Biomacromolecules, 2009, 10, 2533-2538.

39 J. L. Xia, P. L. Dubin, Y. Kim, B. B. Muhoberac and V. J. Klimkowski, J. Phys. Chem., 1993, 97, 4528-4534.

40 K. W. Mattison, P. L. Dubin and I. J. Brittain, J. Phys. Chem. $B$, 1998, 102, 3830-3836.

41 T. Hattori, R. Hallberg and P. L. Dubin, Langmuir, 2000, 16, 9738-9743.

42 E. Seyrek, P. L. Dubin, C. Tribet and E. A. Gamble, Biomacromolecules, 2003, 4, 273-282.
43 K. J. Yeo, E. Hwang, K. M. Min, J. G. Jee, C. K. Lee, K. Y. Hwang, Y. H. Jeon, S. I. Chang and H. K. Cheong, Chem. Commun., 2014, 50, 12966-12969.

44 C. Tribet, I. Porcar, P. A. Bonnefont and R. Audebert, J. Phys. Chem. B, 1998, 102, 1327-1333.

45 M. E. Lienqueo, A. Mahn, J. C. Salgado and J. A. Asenjo, J. Chromatogr. B: Anal. Technol. Biomed. Life Sci., 2007, 849, 53-68.

46 A. Mahn, M. E. Lienqueo and J. A. Asenjo, J. Chromatogr. A, 2004, 1043, 47-55.

47 A. J. Wilson, J. Hong, S. Fletcher and A. D. Hamilton, Org. Biomol. Chem., 2007, 5, 276-285.

48 Y. L. Lo and Y. E. Rahman, Int. J. Pharm., 1998, 161, 137-148.

49 P. Sasisanker, A. Oleinikova, H. Weingartner, R. Ravindra and R. Winter, Phys. Chem. Chem. Phys., 2004, 6, 1899-1905.

50 F. Foglia, P. Carullo and P. Del Vecchio, J. Therm. Anal. Calorim., 2008, 91, 67-72.

51 N. L. Almeida, C. L. P. Oliveira, I. L. Torriani and W. Loh, Colloids Surf., B, 2004, 38, 67-76.

52 D. Romanini, M. Braia, R. G. Angarten, W. Loh and G. Picó, J. Chromatogr. B: Anal. Technol. Biomed. Life Sci., 2007, 857, 25-31.

53 O. N. Ivinova, V. A. Izumrudov, V. I. Muronetz, I. Y. Galaev and B. Mattiasson, Macromol. Biosci., 2003, 3, 210-215.

54 M. van de Weert, M. B. Andersen and S. Frokjaer, Pharm. Res., 2004, 21, 2354-2359.

55 W. Pfeil, Thermochim. Acta, 2002, 382, 169-174.

56 T. Y. Chao and R. T. Raines, Biochemistry, 2011, 50, 8374-8382.

57 P. A. Leland, L. W. Schultz, B. M. Kim and R. T. Raines, Proc. Natl. Acad. Sci. U. S. A., 1998, 95, 10407-10412.

58 G. A. Ellis, M. L. Hornung and R. T. Raines, Bioorg. Med. Chem. Lett., 2011, 21, 2756-2758.

59 T. G. Iversen, T. Skotland and K. Sandvig, Nano Today, 2011, 6, 176-185.

60 X. W. Ding, Y. Liu, J. H. Li, Z. Luo, Y. Hu, B. L. Zhang, J. J. Liu, J. Zhou and K. Y. Cai, ACS Appl. Mater. Interfaces, 2014, 6, 7395-7407.

61 A. Akinc, M. Thomas, A. M. Klibanov and R. Langer, J. Gene Med., 2005, 7, 657-663.

62 R. Berisio, F. Sica, V. S. Lamzin, K. S. Wilson, A. Zagari and L. Mazzarella, Acta Crystallogr., Sect. D: Biol. Crystallogr., 2002, 58, 441-450. 